\title{
LASER CORRELATION SPECTROSCOPY (LCS) AND ITS CLINICAL PERSPECTIVES IN OPHTHALMOLOGY
}

\author{
Karganov Mikhail, ${ }^{1}$ Eskina Erika, ${ }^{2,3}$ Stepanova Maria ${ }^{3}$ \\ ${ }^{1}$ Lab of Physicochemical and Ecological Pathophysiology, \\ Institute of General Pathology and Pathophysiology, Moscow, Russia \\ 2 "Sphere" ophthalmological clinic Ltd \\ ${ }^{3}$ Ophthalmological Department of Federal Medical-Biology Agency of Russia
}

Primljen/Received 17. 10. 2015. god.

Abstract: The method of laser correlation spectroscopy (LCS) is based on the analysis of the spectrum of quasielastic light scatter during coherent monochromatic laser irradiation of micro-particles in biological fluids (blood serum, urine, oropharyngeal washout fluid, tear fluid etc.). Spectrum provides information on dynamic processes in the analyzed system: translation motion of scattering particles and their orientation and conformation dynamics. Special procedures of cluster analysis make it possible to find out to which linkage group a particular spectrum belongs. LCS allows evaluation of sub-fractional composition of biological fluids in a wide range of molecular sizes (from 1 to $10,000 \mathrm{~nm}$ ), which determines principal novelty of this approach in ophthalmology.

Key words: laser correlation spectroscopy, tear fluid, contact lenses, the cornea, PRK, Trans PRK.

\section{INTRODUCTION}

The analysis of tear fluid is a simple, safe and minimally invasive method of investigation. Method of quantitative analysis of tears fluid and functional tests of the tear secretion is used traditionally and mostly long ago (1). In many works of various authors changes of composition of the plaintive liquid (PL) at pathology of the plaintive device were described and scientifically proved generally, and also local metabolic and immune changes of an organ of vision (2). Most of the work is devoted to a comparative analysis of trace element of tear fluid for various common diseases of the body, such as diabetes, eye diseases in general (diabetic retinopathy, primary open-angle glaucoma), as well as after surgery (photorefractive keratoektomiya and laser in-si-
Prihvaćen/Accepted 27. 11. 2015. god.

tu keratomileusis, cataract extraction). Changes of sub-fractional compound of tear fluid after these processes as a result of a variety of local tissue and intracellular processes (3). However, the analysis of these changes was conducted by various methods, which proved to be technically difficult to achieve, or not sufficiently express, or because of low sensitivity. But with laser correlation spectroscopy (LCS) it is possible to record objectively the nature and extent of these changes.

Laser correlation spectroscopy (LCS) (analogs: spectroscopy of quasi-elastic light scatter, optical mixing spectroscopy, photon-correlation spectroscopy) consists of measurement of spectral characteristics of light scattered in quasi-elastic mode from the spectrum of fluctuation intensity of the recorded light (4-9). Two schemes of measurements can be used: homodyne (selective recording of the light scattered by the system) and heterodyne (recording of beats between the scattered light and reference fixed high-intensity light). The spectrum of light intensity fluctuations is a Fourier-transform of a correlation function of intensity fluctuations of the recorded field. In the device used by us, a heterodyne scheme (Figure 1) is applied (5). Helium-neon laser serves as a source of light (2).

Laser beam is divided by a plate (3) and about $0.1 \%$ light beam $(\mathrm{S})$ is separated from the main beam,

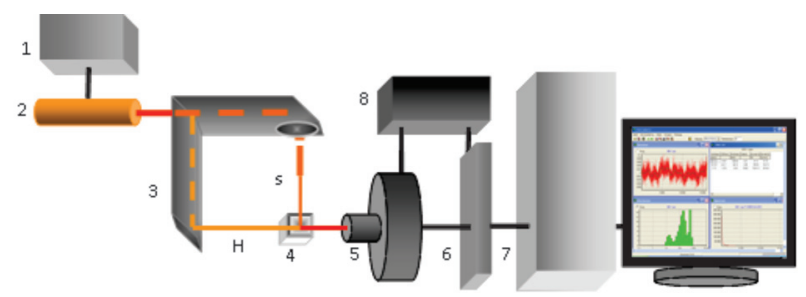

Figure 1. Scheme of laser correlation spectroscope 


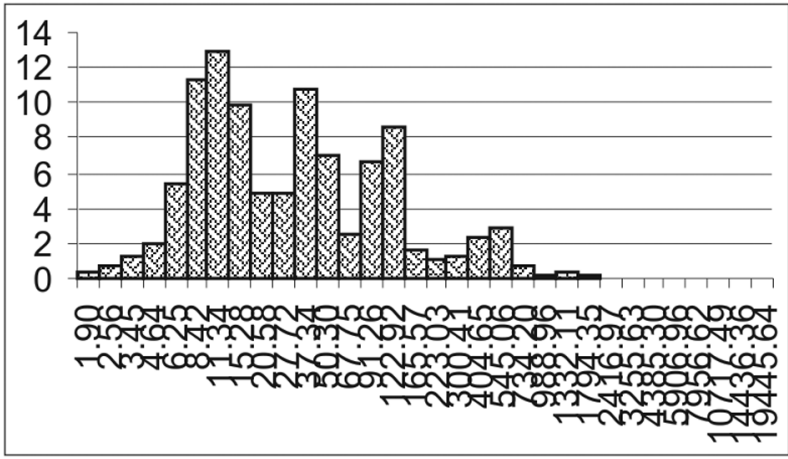

Figure 2. Histogram of size distribution of particles. Ordinate - contribution of particles of the corresponding zone into light scattering (\%). Abscissa-particle size ( $\mathrm{nm}$ )

is transmitted to a photo recorder (5), and is mixed with the scattered portion. Not the spectrum of light scattered by the studied system, but the spectrum of photoelectric fluctuations at the photo recorder (5) output is directly recorded in LCS. This spectrum represents a result of mutual beats of electromagnetic filed harmonics and is located in a low-frequency band.

A histogram of typical size distribution is presented in Figure 2. The size scale is discrete and consists of 32 points.

The distribution histograms in biological fluid provide qualitative information on the mean particle sizes and their relative content. Strict correspondence of certain fragments of the spectrum to biological nature of serum components can be determined after additional studies.

For example, in degenerative and catabolic processes increased activity of hydrolases in interstitial fluid appears low-molecular weight molecules. The recorded spectrum of tear fluid will contribute to increased light scatter low-molecular ingredients - from 10 to $200 \mathrm{~nm}$ (mainly albumin and globulins). When processes are associated with modification of cellular metabolism and the growth of different nature toxicity contribution to light scattering is increasing from 200 to 600 nm (glycoproteins) (10).

Assessment of the severity of the postoperative period and possible complications (including concomitant diseases)

Analysis of tear fluid was conducted in patients after cataract extraction followed by IOL (intraocular lens) and in patients after refractive surgery. With an increase in subjective symptoms, inflammation in the eye was revealed after cataract extraction with IOL implantation in the experimental spectrum of the growing contribution to light scattering high-molecular ingredients (from 400 to $600 \mathrm{~nm}$ ) - a type of heavy glycoprotein complex. It is typical to the processes accompany- ing the increase of inflammatory intoxication. Also, increasing the contribution of high and very high-molecular fractions range (600 - $1200 \mathrm{~nm}$ or more), which is associated with the formation of increased numbers of immune complexes (11). In patients after refractive surgery there was marked prevalence in washouts of tear fluid albumin and globulins, which suggested a tendency to catabolic processes which can be caused by increased activity of hydrolases and due to chronic traumatization of the contact lens (CL) and the damaging influence of the laser directly on the collagen fibres of the cornea, destroyed during ablation, small fragments that give this prevalence in the spectrum of the tear fluid. In the early postoperative period showed an increase in the number of small particles that can be caused by the presence of protein ingredients such as albumins, globulins, growth factors and cytokines protein nature, including transforming growth factor- $\beta$ (TRF-beta), and may also indicate about the growth of the inflammatory response of different nature, including the endogenous nature, which may be due to undergoing surgery and reparative processes occurring after the ablation of the cornea. In the future, the results of this study can be used for screening for monitoring and forecasting process in the postoperative corneal surface ablation $(12,13)$.

\section{Assessment of consequences of wearing soft lenses}

The method of laser correlation spectroscopy has been used to analyze the tear fluid in patients using soft contact lenses (CL) to different wearing experience (5 years and 5 years and more). For the possibility of extending the maximum safe wearing $\mathrm{CL}$, requires an objective assessment of the status of local eyes of these patients. The results of analysis of laser-correlation spectrum revealed that patients using soft contact lenses as a contact lens, dominates presence in the tear fluid glyco-lipoprotein complexes and a relatively high content of immune complexes in comparison with the control group, indicating that the build-up of the inflammatory intoxication of various natures including endogenous character. Many authors have described various disadvantages of the use of contact lenses, such as hypoxia, oedema, corneal epithelial damage, superficial keratitis, micro-cysts, erosion, corneal ulcer, neovascularization, toxic and allergic reactions, infectious eye disease, a syndrome of "dry eye". These complications of the use of the CL lead to various changes in the composition of tear fluid $(14,15)$. In addition to influence on the qualitative composition corneal membrane, contact lenses reduce the supply of oxygen to the corneal epithelium, thus reducing the metabolic rate 
therein. Analysis of the samples between the groups of patients differing in duration of use CL showed that patients with many years of application of this type of contact lens, there was a slight prevalence of middle and low molecular weight components compared to patients using contact lens less than 5 years. People who use CL leads to the predominance in the tear fluid glyco-lipoprotein complexes and a relatively higher content of immune complexes, compared with patients who did not use the contact correction that says about the growth of the local inflammatory intoxication of different nature, including the endogenous nature. These changes may be related to chronic traumatization of the eye surface structures of soft contact lenses $(16,17)$.

It is worth noting that in the study, patients were taken without concomitant ophthalmopathology not instilled in the conjunctive cavity preparations. In addition, patients were used soft contact lenses of planned replacement for a period of wearing 2 weeks. So, what kind of extended wear contact lenses the patient chooses, of course, it will affect the structure of sub-fractional structure of tear fluid and reflect on the results of further research.

\section{The prospects further research (correlation with clinical data and analysis, comparing the effects of different types of transactions, etc.)}

Conducting photorefractive surgery is accompanied by metabolic and immunological changes of eye tissues, which persist for a long time (18). These changes may have a significant impact on the sub fractional composition of the tear fluid. Analysis of samples of tear fluid was conducted in patients undergoing several types of photo refractive surgery: photorefractive keratectomy and trans-epithelial photorefractive keratectomy. In the run-off from the groups of patients on the day after surgery epithelialization it was noted an increase in the number of albumin and globulin fractions, with difference between the groups. In the samples of Tear fluid patients after PRK slightly predominated small-molecule when it was compared with samples of patients after Trans PRK (13\% and 10\%, respectively), which may be associated with a higher precision calculation of the ablation zone during the second type of operation. The presence of middle fractions (glyco-lipoprotein particles) it is possible to assume a tendency to catabolic processes which could be caused by the damaging effects of the laser directly on the collagen fibres of the cornea, destroyed during ablation, small fragments that give this prevalence in the spectra of tear fluid. In the period of 3 months after surgery there was showed an increase in the number of fine particles of tear fluid compared to the control group, which may be due to the presence of protein ingredients, such as albumin, globulin, growth factors, interleukins and cytokines protein nature, including those described actively produced after excimer laser ablation of corneal transforming growth factor- $\beta$ (TRF-beta). The presence of these factions during the early postoperative period and in the period of 3 months after the operation was expected to characterize the activity of reparative processes after corneal ablation.

Excimer laser photorefractive keratectomy and trans-epithelial photorefractive keratectomy have a direct impact on surface structures of the eye, which leads to similar long-life use that we have described the characteristic changes in the composition of the tear fluid sub-fractional (18).

By using enzyme immunoassay method it was analysed pro-inflammatory and anti-inflammatory cytokines in patients undergoing these operations. The results showed a significant increase in the concentration of IL-10 and significant predominance of IL-4 in samples of tear fluid patients postoperatively Trans PRK compared with of PRK, which can be indicative of the suppression of inflammatory reactions during Trans PRK. In two groups the cconcentration of pro-inflammatory cytokines was about the same, except peak group Trans PRK concentration IF- $\gamma$. However, it should be noted that this analysis was conducted on a small group of patients and more significant research in this area is planned for the near future.

The laser correlation spectroscopy is an original technique by means of which it is possible to diagnose initial changes in a forward piece of an eye when objective complications still aren't present on early terms. Besides, further results of the real researches can be used for screening monitoring and forecasting of a course of postoperative process at superficial ablation of a cornea. In addition, by means of this method at early stages, it is possible to correct the mode of carrying soft contact lenses, to appoint trophic therapy with the purpose to exclude and delay complications.

\section{Conclusion}

Based on the results of our study we can conclude that LCS - is express analysis, with which we can diagnose and observe the initial changes in local metabolism in the anterior segment of the eye, when the objective breaches have not seen yet. The observed changes in the direction of metabolic shifts maybe are stochastic and reflect either adaptive or non-adaptive responses of the organism to therapeutic or surgical intervention. More numerous sample and broader range of ef- 
fects in combination with traditional research methods are required for deciphering of the real significance of the detected relationships. Visual analysis of histograms is low-effective for clinical studies; special classification programs are required to enable analysis of data bulk over a short time. The algorithm of classification analysis may be based on methods of the theory of groups. Metabolic deviations, measured by LCS, are due to different external influences. Thus we can suppose the LCS can be an integrative method, useful for experimental and clinical ophthalmological research.

DECLARATION OF INTEREST. None
Abbreviations
$\mathbf{C L}$ - contact lens
IF- $\gamma$ - interferon $-\gamma$
IL - interleukin
IOL — intraocular lens
LCS - laser correlation spectroscopy
PL - plaintive liquid
PRK - photorefractive keratectomy
TRF-beta - transforming growth factor- $\beta$
Trans PRK - trans-epithelial photorefractive keratectomy

\title{
Sažetak
}

\section{LASERSKA KORELACIONA SPEKTROSKOPIJA(LCS) I NJENA KLINIČKA PERSPEKTIVA U OFTALMOLOGIJI}

\author{
Karganov Mikhail, ${ }^{1}$ Eskina Erika, ${ }^{2,3}$ Stepanova Maria ${ }^{3}$ \\ ${ }^{1}$ Lab of Physicochemical and Ecological Pathophysiology, \\ Institute of General Pathology and Pathophysiology, Moscow, Russia \\ 2 "Sphere" ophthalmological clinic Ltd \\ ${ }^{3}$ Ophthalmological Department of Federal Medical-Biology Agency of Russia
}

Metoda laserske korelacione spektroskopije je bazirana na analizi spektra kvazielastičnog rasipanja svetlosti tokom koherentnog monohromatskog laserskog zračenja mikročestica u biološkim fluidima (krvni serum, urin, orofaringealni ispljuvak, suze, itd.). Spektar pruža informacije o dinamskim procesima u ispitivanom sistemu: kretanje rasutih čestica i dinamika njihove orijentacije i građe. Specijalne procedure klaster

\section{REFERENCES}

1. Somov E., Brzheskij V. Tear fluid. Bibliopole Publ., 1994.

2. Stepanova MA, Arhipova EN, Eskina EN, Zikova AV. The prognostic significance of the study of tear fluid to assess tolerance of soft contact lenses. Oral presentation. "Innovations in Science and Education", Section "Modern advances in basic and clinical medicine" - clinical studies. State Classic Academy. 2012; Moscow, Russia.

3. Vineckaja MI, Iomdina EN. The study microelements in tear liquid in certain eye diseases. Vestnik Ophthalmology. 1994; 110 (4): 24-6.

4. Gulari E, Tsunashima Y, Chu B. Photon correlation spectroscopy of particle distributions. J. Chem. Phys. 1979; 70(8): 3965-72.

5. Lebedev AD, Ivanova MA, Lomakin AV, Noskin VA. Heterodyne quasi-elastic light scattering instrument for biomedical diagnostics. Applied Optics. 1997; 36(30): 7518-22.

6. Hautz E, Cao A, Taillandier E et al. Conformational change of core particles studied by quasi-elastic light scattering. Biochem. 1981; 63(11-12): 891-4. analize omogućavaju da se otkrije kojoj povezanoj grupi pripada posebni spektar. LCS omogućava evaluaciju sub-frakcionalnog sastava bioloških fluida u okviru širokog spektra veličine molekula (od 1 do 10 $000 \mathrm{~nm}$ ), što određuje glavnu novinu ovog pristupa u oftalmologiji.

Ključne reči: laserska korelaciona spektroskopije, suze, kontaktna sočiva, rožnjača, PRK, Trans PRK.

7. Horn DS, Dalgleish DG. A photon correlation spectroscopy study of size distributions of casein micelle suspensions. Eur. Biophys.1985; 11(4): 249-58.

8. Hwand IS, Cummins HZ. Dynamic light scattering of collagen. J. Chem. Phys. 1982; 77(2): 616-27.

9. Chu D. Laser light scattering. N.Y.: Acad. Press. 1974.

10. Gancovskij PI. About indications for intraocular correction of aphakia in diabetic patients with varying degrees of severity. Ì.; 2004.

11. Bocharov VE, Bol'shunov AV, Gancovskij PI, et al. Laser correlation spectroscopy of tear fluid in the evaluation of the semiotic nature of postoperative inflammatory reaction and its severity in diabetic patients with implantation of intraocular lenses. Vestnik Ophthalmology. 2003; 6: 30-3.

12. Stepanova MA, Arhipova EN, Medvedeva US, et al. Comparative analysis of the tear fluid at different times after the operation by Trans PRK. V International scientific and practical conference "Actual problems of biology, nanotechnology and medicine”. Rostov-on-Don. 2013; 120-2.

13. Stepanova MA, Arhipova EN, Zikova AV, et al. Evaluation of tear fluid after surgery by Trans PRK. "VII Russian sci- 
entific conference of Young Scientists "Actual problems of ophthalmology". M. 2013; 241-4.

14. Brzheskij VV, Somov EE. Keratoconjunctival sicca, S.-Pb., 2003.

15. Jefron N. Complications of wearing contact lenses and recommendations for their elimination, 1997.

16. Stepanova MA, Arhipova EN, Medvedeva US, et al. Evaluation of body metabolism due to prolonged use of soft contact lenses. "XII Russian School ophthalmology". M. 2013; 395-9.
17. Stepanova MA, Arhipova EN, Medvedeva US, Karganov MU, Eskina EN. The role of changes in subfractional composition of tear fluid in the evaluation of the damaging effect of soft contact lenses, and excimer laser ablation of the cornea for the correction of ametropia. Pathol. Physiol. Exp. Ther. 2014; 1: $32-6$.

18. Kurenkov VM, Majchuk DJu, Kashnikova OA. Therapy syndrome of "dry eye" before and after photorefractive surgery. Dry eye. Bibliogr. 2002; 2: 12-14.

\title{
Correspondence to /Autor za korespondenciju
}

\author{
M. A. Stepanova
}

Starokachalovskaya street, 10

Russia, Moscow

Email: m.stepanova@sfe.ru 